Volume 2, Number 1, 2016

\title{
Controlled Switched Reluctance Motors with Energy Capacitor
}

\author{
Vasyl Tkachuk, Lidiya Kasha*, Ihor Bilyakovskyy, Mykhajlo Haj \\ Lviv Polytechnic National University, 12, S. Bandery St., Lviv, 79013, Ukraine
}

Received: June 30, 2016. Revised: November 28, 2016. Accepted: December 23, 2016

(C) 2016 The Authors. Published by Lviv Polytechnic National University.

\begin{abstract}
One of the most simple in terms of construction, the most practically feasible and reliable motors is a switched motor with salient-pole stator, concentrated coils and its winding and toothed passive rotor. Such motor is simpler, cheaper and more practically technical than asynchronous motor and by control characteristics does not concede to DC motors. The basic electrical scheme of a commutator with capacity buffers of energy of switched reluctance motor and circumscribed, the new phase-width mode by regulating frequency of reversion of such drives is offered. The width-phase speed control, where there is a functional relationship, is described in this paper.
\end{abstract}

Keywords: switched reluctance motor; width-phase control; energy capacitor; electronic commutator.

\section{Introduction and problems, which are appeared}

Wide distribution of the switched reluctance motors (SRM) is kept back by low energy coefficients. That is the cause of dispersing the energy which is accumulated in electromagnetic field during current commutation by transistors in section, and which is the condition of overvoltage protection. Striking example of this problem is the SRM with half-wave stabilitron commutator [1]. Therefore, problem of developing the brash-less motor on the basis of simple, cheap and technological inductor motor is added up to the necessity to create new electrical schemes, which will permit to use energy accumulated in magnetic field of rotor winding's section, for execution yield. Structural and schematic circuits of electronic commutator are designed on the basis of electrical machines in the decision of this problem. This commutator is more reliable in service and supply recuperation of energy in magnetic field of section which are commutated [2].

Structural and schematic schemes of electronic switches with high reliability which ensure the re-usage of the magnetic field energy sections that commute [3] are developed by the department of electrical machines of Lviv Polytechnic National University in addressing this problem.

Complexity of SRM can be used for the execution of not only setting in motion mechanism, but also for pointto-point operation, torque drive etc. Availability of full-drive electronic reverser (electronic commutator) (EC) and primary rotor position sensor (RPS) allows organizing different mode of drive operation without small power additional schemes of forming the regulation signals [8].

Choice of the operating mode depends on concrete mode conditions and type of electromechanical converter. Pulse-impulse modulation is acceptable for electromechanical converter (EMC), but it is the cause of increase in the losses on power transistors switches [5]. Width-pulse modulation causes the extra losses from higher harmonics in electromechanical converter and increase in dynamic losses on transistor switches [6]. It is necessary to supplement the use of automatic control system for stiff speed-torque characteristic by the above mode of regulation.

\section{Addressing the problem and discussion of the research results}

Width-phase regulation employment allows getting rigid speed-torque characteristic without the organization of the automatic control additional system. Main point of the method consists in the fact that the forced interval of

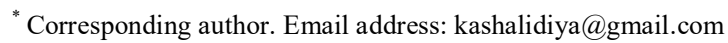


commutation of the SRM section is formed by logical multiplication of the RPS signals and signals of time delay oscillator. This is due to the change of average voltage value which is supplied to the SRM section. Thus the creation of such method for SRM speed regulation is the goal of the paper.

Schemes and diagrams of impulses of three-section SRM with one-wave electronic commutator and width-phase regulation are given in fig. 1.

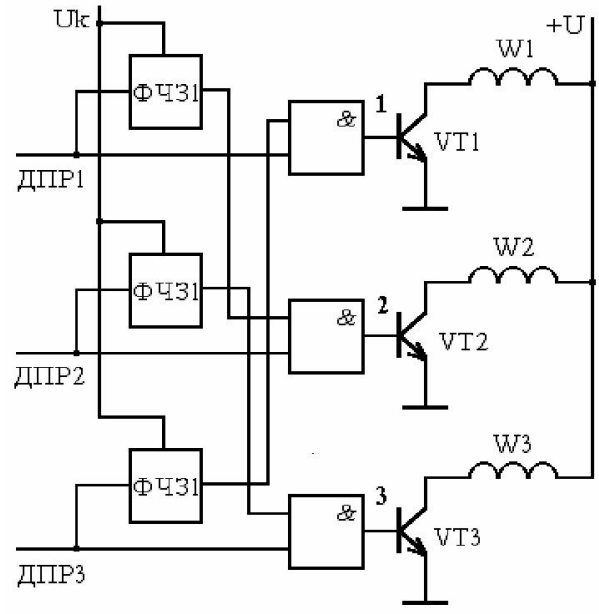

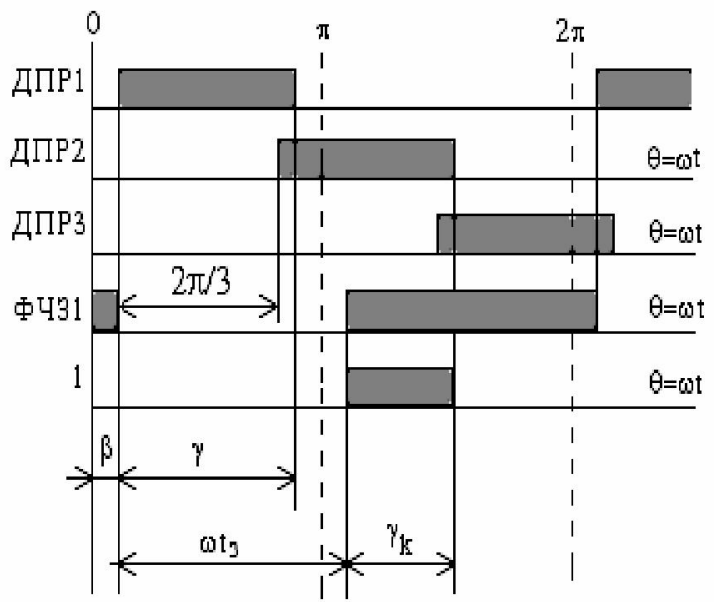

Fig. 1. Simplified (a) and impulse (b) diagrams of SRM with width-phase regulation

Sections of SRM $\mathrm{w}_{1}-\mathrm{w}_{3}$ are connected to DC voltage source U through power switches of EC VT1 - VT3. Output signals ДПР1 - ДПР 3 of RPS take control of power switches through regulation schemes, which consist of time delay creators $\Phi Ч 31$ - ФЧ33 and logic scheme \&. Value of time of delay $t_{3}$ is detected by signal $\mathrm{U}_{\mathrm{k}}$. Impulse of RPS was characterized by angle of signal sector $\gamma_{\mathrm{k}}$ in electric radians and start phase of forced commutation interval of section $\beta$. Output impulses 1-3 of controlled schemes detected forced interval of SRM section commutation $\gamma_{\mathrm{k}}$ in electric radians. Average voltage, applied to section of SRM, is characterized by rotation speed and relative value of forced commutation interval [4]

$$
d=\frac{\gamma_{k}}{\pi}
$$

Width-phase regulation employment allows taking regulation characteristics at the expense of relative commutation interval variation by amplitude and phase. At the same time functional connection is obtained and it was equal to negative feedback. Thanks to last inflexibility of speed-load characteristics.

The problems of creating new type of electrical motors, which include salient-pole switched reluctance motors with capacity storages of energy, will be solved successfully only using precision tools for the calculation of the static and dynamic characteristics of SRM.

Nowadays, series of theories are created. All of them allow calculating periodic processes in electromechanics, that is to say when currents, interlinkage, voltages, angular and linear motions were periodic time functions.

For m-sections EMC with passive rotor, magnetic insulated sections and electronic commutator with series capacity storages in each of section, the mathematical model of SRM are described by the next system of differential equations (2) [7]. Given mathematical model [6] is the basis for making the numeric models of electric drives with switched reluctance motors with capacity storages. It is enough to apply operators which modeling synchronized signals time delay and multiple of it on according RPS's signals in equation of absolute $\mathrm{K}_{\mathrm{j}}$ for creating the computer simulation of electromechanical process of SRM with width-phase regulation [2, 4].

\section{Results of computer simulation}

The example of computer simulation of section, capacitor voltage and electromagnetic torque of 3-section SRM with width-phase regulation and series capacity storage in each of section is given in Fig. 2. 


$$
\left\{\begin{array}{l}
\frac{d i_{j}}{d t}=\left[u_{j}+R \cdot i_{j}+\frac{A_{j}}{L_{\sigma}}\left(u_{j}-R \cdot i_{j}+R_{S} \cdot i_{S j}\right)-B_{j} \omega\right] / A_{j} \\
\frac{d i_{S j}}{d t}=-\left(R_{s} i_{S j}+u_{j}-R \cdot i_{j}\right) / L_{\sigma} \\
\frac{d u_{C j}}{d t}=\left(1-K_{j}-K_{j+m}\right) \frac{i_{j}}{C} \\
\frac{d \omega}{d t}=\left\{\sum_{j=1}^{m}\left[\frac{Z_{r}}{2}\left(i_{j+i_{S j}}\right) \cos \theta_{p j} \cdot \psi_{y} \times\left(1-e^{-a\left(i_{j}+i_{S j}\right) \sin \theta_{p j}}-\frac{\psi_{l t}\left(i_{j}+i_{S j}\right)}{2 \psi_{y}}\right)\right]-M_{C}\right\} \frac{Z_{r}}{J} \\
\frac{d \theta}{d t}=\omega
\end{array}\right.
$$

Mathematical model (2) given in paper can be used for calculating the static characteristics of electric drive on the basis of SRM with buffer of energy and width-phase regulation of the rotation speed. To do this, nonlinear system of differential equations will be integrated by different value of load moment and constants of all other parameters.

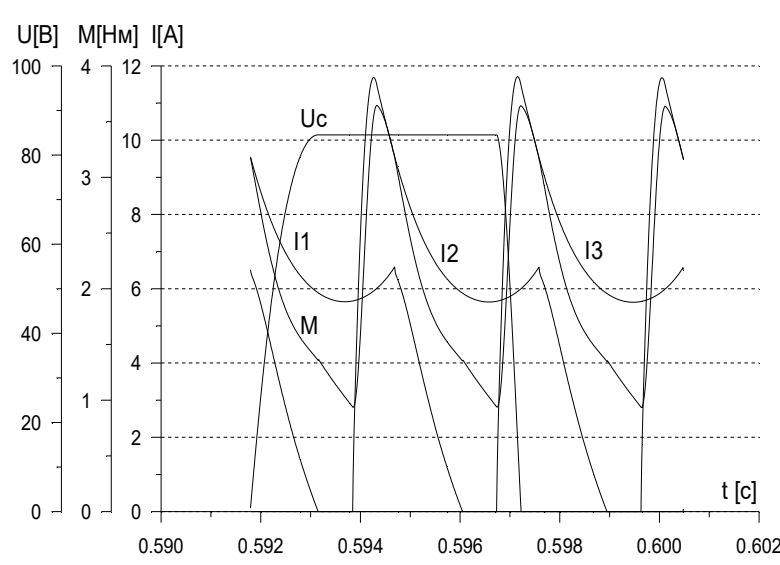

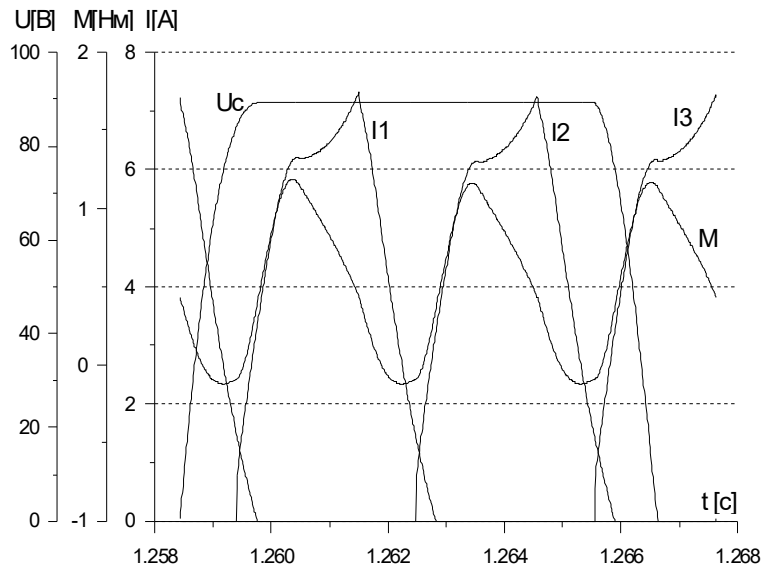

b

Fig. 2. Current of section, voltage on capacitor and electromagnetic torque of SRM with width-phase regulation:

$$
\mathrm{a}-\text { load moment } 2 \mathrm{Nm} \text {; b - load moment } 0.5 \mathrm{Nm}
$$

Results of computer simulation of the natural and custom-made static characteristic of SRM by voltage $24 \mathrm{~V}$, switch-on angle $\beta=10$ electric degree, commutation interval $\gamma_{k}=145$ electric degree, capacity storages $20 \mathrm{mcF}$. Value of time delays -5 and 3 mksec accordingly for curves 2 and 3 are shown in Fig. 3.

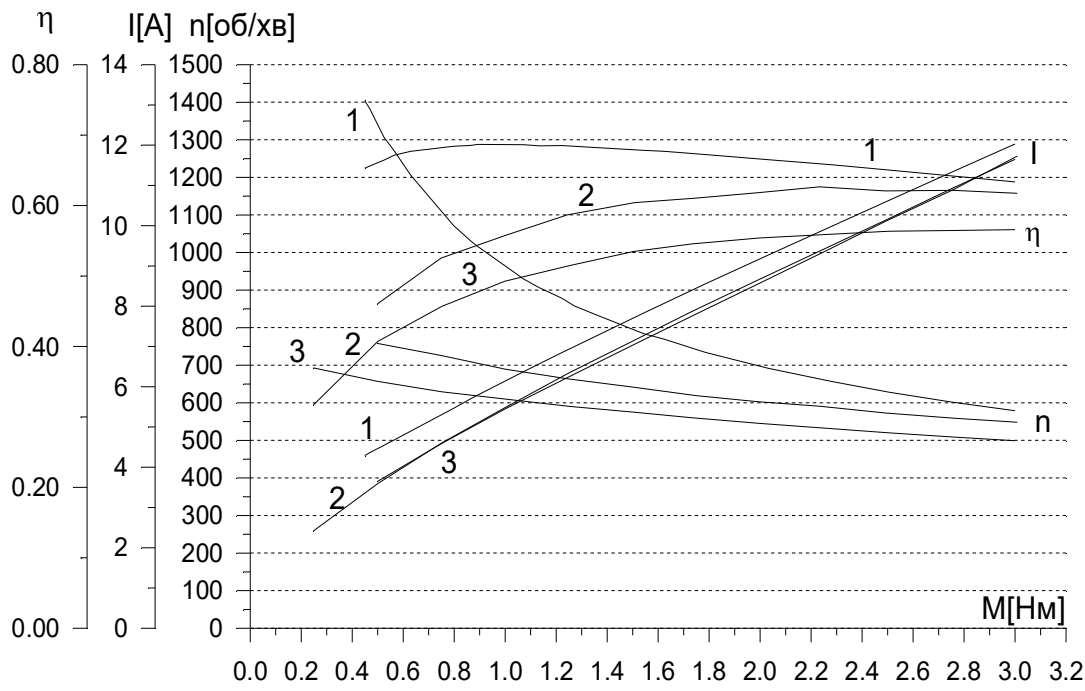

Fig. 3. Static characteristic of SRM with buffer of energy and width-phase regulation 


\title{
4. Conclusions
}

Width-phase control methods in EC of SRM allows, in a simple way, getting speed characteristics due to changes in magnitude and phase of enforced section switching interval .

Comparison of calculation results with the experiment oscillation diagrams, and also average value of torque, speed of rotation and parts of losses for SRM prototypes with nominal torque from $0.05 \mathrm{Nm}$ till to $20 \mathrm{Nm}$ are indicated that differences are not above $5 \%$. Adequacy of mathematical model (2) to SRM prototype is the result of that.

\section{References}

[1] Miller T. J. E. Switched Reluctance Motors and Their Control, Magna Physics Publishing. - Cladrendon Press-Oxford, 1993 , pp. 76-82.

[2] Tkachuk V. I., Kasha L. V. Switched reluctance motor with serial capacity storage and its mathematical model, Proc. of ISTC UEES-01, vol. 3 , 2001, pp. 953-960 (in Poland).

[3] Tkachuk V. I., Greschuk O. V. "Controlled electric drive on the base of switched reluctance motor", Electrical machines design and electrical equipments. Special issue. Kyiv, No. 66, 2006, pp. 56-58 (in Ukrainian).

[4] Tkachuk V. I., Gajduk V. G., "Control methods of rotational speed of brush-less motor", Proc. of Lviv Polytechnic National University: Electrical and electromechanical systems, No. 421, 2001, pp. 202-207 (in Ukrainian).

[5] V.I. Tkachuk, L.V. Kasha, "Pulse-width regulation of switched reluctance motor with capacity storages", Scientist journal "Proceedings of Lugansk department of International informatization Academy", No. 1(8), 2004, pp. 59-65 (in Ukrainian).

[6] Tkachuk V. I. "Switched reluctance motor and its mathematical model", Scientific and technical collection. Theoretical electrotechnic. Lviv Publishing House "Svit", vol. 54, 1998, pp. 121-127 (in Ukrainian).

[7] Tkachuk V., "Computer-aided research sub-system of switched reluctance motor", Technical electriodynamic, 1998, pp. 180-187 (in Ukrainian).

[8] Tkachuk V. and Osidach Yu., "Transistor commutator with capacitive buffer of energy", Proc. of Lviv Polytechnic National University: Electrical and electromechanical systems, Lviv Polytechnic National University, 1996. No. 301, pp. 115-122 ( in Ukrainian).

\section{Керовані вентильні реактивні двигуни з буферами енергії}

\author{
Василь Ткачук, Лідія Каша, Ігор Біляковський, Михайло Хай \\ Національний університет «Львівська політехніка», вул. С. Бандери, 12, Львів, 79013, Україна
}

\section{Анотація}

Одним з найпростіших за конструкцією, технологічним і надійним є вентильний двигун (ВД) зі зубчастим пасивним ротором. Закладену уже принципом роботи складність ВД варто використати для позиційного, моментного тощо приводів. Наявність повністю керованого електронного інвертора та первинного давача позиційного зворотного зв'язку дає змогу із залученням тільки малопотужних додаткових схем формування керувальних сигналів організовувати ці режими роботи. Вибір способу регулювання залежить від конкретних умов роботи приводу і типу електромеханічного перетворювача: амплітудноімпульсна модуляція, широтно-імпульсна модуляція, дискретно-фазові способи регулювання. Проте такі системи мають суттєвий недолік, який полягає в низькій перевантажувальній здатності. Запропоновано широтно-фазовий спосіб регулювання частоти обертання ВД, за якого існує функціональний зв'язок, який еквівалентний за дією від'ємному зворотному зв'язку за швидкістю, що підвищує жорсткість механічних характеристик.

Ключові слова: вентильний реактивний двигун; буфер енергії; широтно-фазове керування; електронний комутатор. 